\title{
Applied Cultural and Social Studies are Needed for a Sustainable Reduction of Genetic Disease Incidence
}

\author{
Jens Staal ${ }^{1,2 *}$
}

${ }^{1}$ VIB-UGent Center for Inflammation Research, Unit of Molecular Signal Transduction in Inflammation, VIB, Ghent, Belgium

${ }^{2}$ Department of Biomedical Molecular Biology, Ghent University, Ghent, Belgium

*Corresponding Author: jens.staal@irc.vib-ugent.be

Citation: Staal, J. (2017) Applied Cultural and Social Studies are Needed for a Sustainable Reduction of Genetic Disease Incidence. European Journal of Sociology and Anthropology, 2(1), 01. doi: $10.20897 /$ ejsa.201701

Published: June 15, 2017

\begin{abstract}
While clinical and basic biomedical research focus on diagnoses and cures for common and rare genetic diseases, they are unable to address one of the largest underlying causes for genetic disease: mating within families or other small genetically isolated sub-populations. This interdisciplinary literature study investigates theoretical, moral and practical aspects to solve this major cause for genetic disease from an alternative angle: through cultural change and encouragement of an outbreeding reproductive behavior. Understanding why some communities persist with choosing consanguineous reproductive partners when the modern society has eliminated the economic rationale to do so, and to develop strategies to encourage a cultural change in those communities, is critical for a sustainable long-term solution to reduce the number of new cases of genetic disease and undiagnosed (sub-clinical) but detrimental genetic abnormalities in vulnerable and marginalized groups in modern Western societies.
\end{abstract}

Keywords: genetics, acculturation, public health, consanguinity, social engineering

\section{INTRODUCTION}

Already Charles Darwin noticed that inbreeding led to genetic problems and he felt personally responsible for the poor health of his children, since he was married to his first cousin Emma Wedgwood and the whole family had a history of multi-generation consanguinity (Berra et al., 2010). One of the first systematic studies regarding health issues related to inbreeding in humans was performed by Charles Darwin's son, George Darwin (Anderson, 1986). At the time, kin marriages were common in Europe but the realization of the genetic risks coupled with social change, increased mobility and urbanization rapidly reduced the practice and it became a social taboo in many Western societies (Anderson, 1986; Egerbladh and Bittles, 2011; Kuper, 2002; Rao et al., 1972; Rudan et al., 2008; Sutter and Goux, 1964). The practice of kin marriage is also expected to decrease globally (Bittles and Black, 2010; Jaber et al., 2000), but is still very common (Hamamy et al., 2011). At this moment, the public health care system is often confronted with rare genetic diseases from immigrant communities practicing kin marriage (Anwar et al., 2014; Hamamy, 2012; Schulpen et al., 2006). Economic studies have suggested models of a "failed marriage market" which leads to kin marriage as a rational choice (Do et al., 2012). This proximal rational economic choice does however lead to ultimate issues with an accumulation of detrimental genetic variants within families, which can manifest as disease or sub-clinical defects (Adams and Neel, 1967; Al Talabani et al., 1998; Al-Gazali and Hamamy, 2014; Barbouche et al., 2011; El Mouzan et al., 2008; Magnus et al., 1985; Morton, 1958; Rezaei et al., 2006; Sheridan et al., 2013). Evolutionary theoretical models could also argue for some positive effects from consanguinity by rapidly selecting for beneficial recessive genetic variants which ultimately might benefit the population under a certain environmental selection pressure (Denic et al., 2008, 2011). This type of selection does 
however come at a great individual cost which can not be acceptable in modern society (Bittles, 2011). It is also questionable if inbreeding-accelerated selection as done in artificial breeding of desirable traits actually give longterm benefits under a complex evolutionary pressure: some traits critical to survival, like immunity to novel pathogen threats, greatly benefits from high genetic diversity and outbreeding (Hoben et al., 2010). In fact, given a free mate choice it seems like humans tend to select mates with dissimilar immune genes, supposedly to ensure high diversity of immune genes in their offspring (Chaix et al., 2008; Grob et al., 1998; Havlicek and Roberts, 2009). It is also possible that additional mechanisms of selection in free human mate choice are specifically aiming for enhanced diversity (Berghe, 1983; Thelen, 1983). The culture of within-family mate choice does however persist in many immigrant communities (Anwar et al., 2014; Reiners, 2001; Schulpen et al., 2006; Shaw, 2001; Stoltenberg et al., 1997), where many of the suggested economic (and possibly biological) reasons for this practice should be moot. Surprisingly, there are indications that the practice of kin marriage might be more preserved in recent generations among immigrants compared to the situation in their country-of-origin (Baykara-Krumme, 2016; Darr and Modell, 1988). I propose that we need a collaborative effort spanning the "three cultures" of Natural sciences (including medicine), Social sciences and Humanities (Kagan, 2009) to reach a sustainable solution to many cases of genetic disease through encouragement of a cultural change in groups where consanguinity is still frequent. Interdisciplinary efforts including "the other" academic cultures has been found to be problematic in biomedical sciences due to low opinions of the social sciences and humanities among many biomedical scientists (Albert et al., 2008; Kuntz, 2012). Since the problem described here is mainly social and cultural, the dynamics might look different since only limited input (identifying groups with high risk of genetic disease, and factual insights on the risks of inbreeding) from the biomedical field is needed.

\section{TREATING THE SYMPTOMS WITH BIOMEDICAL SCIENCE}

\section{Advances in technology and knowledge through basic biomedical science, and its limitations}

Advances in knowledge about the biological mechanisms and an ever expanding catalog of genetic defects increases the chances of genetic testing for diagnosis of rare conditions. There can be a discrepancy between the clinical characterization of a disease (a diagnosis) and its genetic foundations, for example can a single disease as defined by its clinical presentation be caused by multiple independent genetic mechanisms (for example psoriasis, (Tsoi et al., 2017)). On the other hand can a single genetic aberration also manifest as different diseases. For example, one of the most common pathological genetic aberrations (22q11.2DS; present in up to 1/2000 live births) results in two different diseases (OMIM 188400 and 192430; (Amberger et al., 2015)) but is most likely under-diagnosed and also results in many lesser defects within the "normal" spectrum (Fung et al., 2015). Because the complex relationship between genetics and clinical manifestation of disease, one major contribution of clinical and basic research is identification of genetic markers for more accurate and sensitive diagnosis. A proper diagnosis can as such give a relief to the patient and the care giver, since giving the condition a name makes it more "real" (Rich, 2016). Recently, extensive catalogs of knock-out mutations in the human genome have been facilitated by applying the rapidly evolving genome sequencing technology on inbred human populations (Saleheen et al., 2017; Sulem et al., 2015). This resource together with mouse genetic models and the ability to edit the genome in model cell lines using tools like CRISPR/Cas9 has - and will - greatly enhance our understanding of the function of the genes and the proteins they code for and how these functions are related to disease. Fundamental understanding of the mechanisms causing disease can in turn lead to more effective and targeted treatments. Genome editing (with for example CRISPR/Cas9) also holds the promise to be able to correct for a genetic defect in induced pluripotent stem cells (iPSC), which then can be re-introduced to the patient to replenish the relevant cell-type with a healthy variant which otherwise is genetically identical to the patient (Hotta and Yamanaka, 2015). Knowing the mechanism of the disease and replenishing with a healthy variant of the relevant cell type can sometimes result in remarkable recoveries (Rozmus et al., 2016). These technological trends are highly promising for treatments of individual patients but are no substitute for avoiding disease altogether, since many genetic diseases (especially those affecting the patient during embryo development) will be impossible to cure. Simply put, prevention is the best cure - for example through in vitro fertilization (IVF) and pre-implantation genetic screening. This is however an expensive and invasive procedure, and a practice that has been ethically challenged as a form or eugenics (King, 1999). Alternatively, through encouragement of reduction of risks through the selection of reproductive partner either through genetic counseling (Meyer, 2005) or by encouraging outbreeding. The latter approach is naturally the most sustainable but outside the realm of biomedical science.

\section{Lost in Translation: the relationship between the patient and basic biomedical science}

Basic studies of the fundamental mechanisms of disease are rarely performed by clinicians themselves but rather by non-physician scientists with no contact with the patients, which means that basic scientists and clinicians often 
talk different "languages" (Restifo and Phelan, 2011). This causes an emotional detachment from the patient in basic biomedical research, and a rare or odd genetic error is treated as an exciting and interesting specimen. Since basic research focuses on figuring out how things work and by studying something that is broken (like a genetic mutation causing disease), we learn more about how the intact system is supposed to work. This curious attitude is naturally good for a scientist but would work poorly in a situation with direct contact with patients and their families. This difference in attitude can also be a conflict of interest, where the curiosity-driven research have different aims from the aim to ultimately help patients through discovery of novel opportunities for diagnosis or treatments. A big challenge is thus to encourage application-inspired but still curiosity-driven basic research and to encourage transfer of knowledge from basic biomedical science to the clinic as efficiently and practically as possible (Morris et al., 2011).

\section{Problematic patient expectations on basic biomedical science from media reports and popular culture}

The natural sciences have a very high status in our society (Kagan, 2009), which is partially shaped by the images of scientists as extremely potent miracle-workers (for good or evil) in popular culture and literature (Haynes, 2003; Kirby, 2008). This often leads to high and unrealistic expectations from sufferers of diseases with no current treatment that there - somewhere - is a miracle cure hidden away in a lab. The truth is sadly far more mundane and slow, with an average time frame of years to decades from initial basic discovery (which also is a slow and tedious process) until a treatment reaches the clinic (Morris et al., 2011). I have personally experienced this in basic biomedical research, far away from a usable treatment, that reports of a new mechanism to target in general for autoimmune diseases (Coornaert et al., 2008) or specifically for multiple sclerosis (Mc Guire et al., 2014) or psoriasis (Afonina et al., 2016) led to a media spin which gave many sufferers of these diseases false hopes. These high expectations on what science can deliver on a short term basis is an ethical problem in science communication (Bubela et al., 2012). It also leads to frustration from patients with rare and difficult-to-diagnose diseases, which believe that the lack of research or treatment options is due to lack of interest (Rich, 2016). On the other hand is tempering the hopes for an effective treatment to more realistic expectations within the health care system also problematic (Wiles et al., 2008).

\section{PREVENTING (SOME) CAUSES THROUGH CULTURAL CHANGE}

\section{Awareness and attitudes towards the genetic risks of inbreeding}

As with many complex human conditions, the genetic effects on birth defects are confounded with social and economic situations (Ahmad, 1996; Bittles, 2008), but accounting for those variables, consanguinity is still a major variable in explaining birth defects among vulnerable populations (Sheridan et al., 2013). Social cohesion by family ties is often a major argument in favor of consanguinity, and some groups take it to the extreme (Bittles and Small, 2016; Do et al., 2012). Qualitative studies of the attitudes among groups with high rates of consanguinity and resulting genetic defects, revealed several potential explanations for the continued practice (Ajaz et al., 2015; Joseph et al., 2015; Teeuw et al., 2014). Among the major factors across the studies was lack of information, which is an especially saddening finding since it means that the parents of the affected patients were unaware of the risks. Dealing with genetic risks is a very social issue which involves the entire family (Richards, 1993), and not only the individual patient. Being informed also seems to positively correlate with willingness to help address the issues of consanguinity and genetic disease through, for example, genetic testing (Raz et al., 2003). Responding to information about the risks also requires some basic understanding of genetics (Panter-Brick, 1991; Shaw and Hurst, 2008; Shiloh et al., 1995), but information and counseling can lead to future risk-avoiding behaviors (AbdelMeguid et al., 2000; Frets et al., 1990; Shaw, 2011). On an encouraging note, the practice of kin marriage is on the decline in many different populations with traditionally very high levels of consanguinity (Jaber et al., 2000; Koc, 2008). Many respondents in the UK Pakistani survey also highlighted the need for a more culturally sensitive health care system (Ajaz et al., 2015). Addressing the lack of information (with an implied moral judgment) and cultural sensitivity from health care providers and genetic councilors could however be conflicting aims (Devillé et al., 2011). Since many populations suffering the effects from high frequencies of consanguinity are Muslim, it can be interesting to note that Islam is not promoting kin marriage and is generally positive towards genetic counseling and information about genetic risks (Akrami and Osati, 2007; Al Aqeel, 2007; Ma, 1999). That cultural change can have clear health benefits has been seen in a UK Pakistani sub-population with traditionally very high levels of kin marriage, but where there are trends of a relaxation of this practice in some regions in later generations (Small et al., 2016; Zaidi and Shuraydi, 2002). 


\section{Self-perpetuating marginalization and genetic self-mutilation}

Some groups persist in maintaining an internal marriage pattern (endogamy), despite that multi-generation inbreeding and genetic founder effects are well-known causes of prevalent genetic disease (Patton, 2005). When marriage is not strictly within the family, but still arranged with closely allied families over several generations (Do et al., 2012), this can also cause a detrimental inbreeding situation, as exemplified by the Darwin/Wedgwood dynasty (Berra et al., 2010), but also current genetically isolated populations where endogamy is frequent (Bittles, 2005). The detrimental effects of inbreeding depression might however not always be pathological and still have negative effects for the affected group. It has long been known that detrimental alleles typically are recessive (Jones, 1917), which means that high genetic diversity is beneficial. In agreement with this is higher levels of heterozygosity linked to generally higher health status in a population (Rudan et al., 2006). It is also important to remember that only very severe (pathological) abnormalities are registered by the health care system, which means that genetically perpetuated sub-clinical issues that could lead to poorer well-being, lower intellectual capabilities or other disadvantages that are generally unknown. These "non-pathological" aspects of health are also relevant to take into account in social and cultural approaches to health improvements (Levin and Browner, 2005). These sub-clinical genetic disadvantages can possibly also act synergistic with socioeconomic (environmental) disadvantages (lack of education, network, discrimination and possibly epigenetic inheritance (McGuinness et al., 2012)) to perpetuate the marginalization or social inequality to the next generation (Abu-Rabia and Maroun, 2005; Marioni et al., 2014; Sniekers et al., 2017; Turkheimer et al., 2003; Tuvblad et al., 2006). This potential vicious interaction between genetic and socioeconomic disadvantages might also be further exacerbated by that it is primarily groups with low socioeconomic status that show frequent kin marriage (Barbour and Salameh, 2009; Jaouad et al., 2009; Saadat et al., 2004). There are thus many reasons, both at a societal level and at an individual level, to aim for a modernization of the mate choice in groups that currently maintain a traditional consanguineous marriage tradition for a longterm social change. A similar genetic persistence of economic disadvantages might also exist on a macroeconomic level (Jaber et al., 1998), where some countries or regions carry a heavier burden of genetic disease through widespread kin marriage or small founder populations with limited genetic exchange (Bittles et al., 1991; Rudan et al., 2006; Verma, 2000).

\section{Challenge: respectful encouragement of cultural change in the choice of reproductive partner}

It is problematic for the majority society to influence the mating patterns of vulnerable and marginalized subpopulations, since it can be expressed as some form of racism (Ahmad, 1996) or eugenics (Kerr and CunninghamBurley, 2000; King, 1999). The proposed strategy of encouraging outbreeding is however orthogonal or perhaps even antagonistic to eugenics, since it does not aim to eliminate detrimental alleles as in traditional breeding and eugenics - the aim is rather to make sure that (usually rare) detrimental alleles do not become common in small genetically isolated populations in order to reduce the risks of genetic disease. It is however also very easy to criticize social engineering efforts to change mating patterns in minority groups as a colonialist attitude leading to forced assimilation (westernization, modernization). Some sort of moderate assimilation (or perhaps more accurately: acculturation) strategy is however on its way back in different immigration theories and policies (Alba and Nee, 1997; Brubaker, 2001; Gans, 1997), making it easier to argue for social engineering initiatives with a clear purpose to change cultural behaviors with negative health effects (like kin marriage). Accepting certain phenomena under the guise of cultural sensitivity or relativism is also problematic in a health care situation from an ethical perspective, if a patient first and foremost is seen as a member of a particular group rather than as an individual with needs and rights (Devillé et al., 2011). The right to (a broad definition of) health has been recognized as a universal human right (Hunt, 2007; Pillay, 2008). The resurgent focus on universal human (individual) rights in contrast to the postmodern cultural relativism is sometimes referred to as neo-modernism, where cultural practices respecting human rights are seen as morally superior to those that do not (Alexander, 1994). It is wrong if individuals are treated differently due to their sexuality / gender / ethnic / religious / cultural attributes in the name of cultural relativism (Kymlicka, 1995; Tilley, 2000; Zechenter, 1997), since this is a form of discriminatory Apartheid (literal meaning: "differentness") even if based on well-intended cultural sensitivity. Because of this, it is important that the problem of kin marriage (and associated issues related to individual autonomy vs arranged marriage) is approached with a respectful, (neo-) modern (universalist) attitude by putting the needs of the individual first. An important part of this respectful approach is to be critical of the cultural practices leading to inbreeding, while still not blaming the individual victims of those cultural practices (for example, the parents of a sick child). 


\section{CONCLUSIONS}

While clinical and basic biomedical research focuses on the problems here and now by looking for treatment strategies and cures, which are of critical importance, it is also important to acknowledge that a more sustainable and humane solution would be to make sure that fewer people suffering from genetic disease are born, which can be done by choice of reproductive partner. Ethically, we have no moral obligation towards a particular set of hypothetical unborn individuals which will never be born due to the choices we make in the present (Kavka, 1982). Considering the doubled risk of genetic abnormalities in offspring from first cousins (Sheridan et al., 2013) (a risk that is potentially even greater in multi-generation first cousin unions or highly inbred populations), it would make a lot of sense to do targeted public investments for cultural change in mate choice in sub-cultures (often immigrant or religious communities) with high risk of genetic disease. It is however important to note that the vast majority of children are healthy also in groups where genetic abnormalities are common due to inbreeding (Bittles, 2013). Cultural changes in mate choice will also touch upon other pressing social issues such as female emancipation and individual rather than family-directed mate choice (Zaidi and Shuraydi, 2002). Such social engineering (or educational) efforts will most likely be more effective if performed by experts on social interactions and cultural aspects of modernization, rather than as an initiative from (medical) health care professionals. Finding the most effective strategies to inform and influence is however critical. Experiences with attempts to change attitudes through film show promising results for starting a discussion about the issues despite initially hostile (traditionalist) attitudes (Raz, 2003). Also family-centered outreach strategies have been tried (Darr et al., 2013), with positive results. The health care system is sometimes ill-equipped to encourage a cultural change (Darr et al., 2013), and it is also ethically problematic for a health care provider to also pass judgment on customs (Bennett et al., 2002; Modell and Darr, 2002; Rao et al., 2009). Because of this, the field of clinical genetics usually focus on diagnosis and counseling for individual patients (Bittles, 2001; Hamamy, 2012), but will not address the cultural cause of the problem at a societal level. Considering the high costs (both for the public health economy and the personal suffering and emotional distress for the patients and their parents), it is likely that there will be high long-term gains from a respectfully targeted investment for cultural change in vulnerable groups.

\section{REFERENCES}

Abdel-Meguid, N., Zaki, M. S., and Hammad, S. A. (2000). Premarital genetic investigations: effect of genetic counselling. East. Mediterr. Health J. Rev. Sante Mediterr. Orient. Al-Majallah Al-Sibhiyah Li-Sharq Al-Mutawassit 6, 652-660.

Abu-Rabia, S., and Maroun, L. (2005). The effect of consanguineous marriage on reading disability in the Arab community. Dyslexia 11, 1-21. doi:10.1002/dys.271.

Adams, M. S., and Neel, J. V. (1967). Children of Incest. Pediatrics 40, 55-62.

Afonina, I. S., Van Nuffel, E., Baudelet, G., Driege, Y., Kreike, M., Staal, J., et al. (2016). The paracaspase MALT1 mediates CARD14-induced signaling in keratinocytes. EMBO Rep. 17, 914-927. doi:10.15252/embr.201642109.

Ahmad, W. (1996). "Consanguinity and Related Demons: Science and Racism in the Debate on Consanguinity and Birth Outcome," in The Social Construction of Social Policy Explorations in Sociology., eds. C. Samson and N. South (Palgrave Macmillan UK), 68-87. doi:10.1007/978-1-349-24545-1_5.

Ajaz, M., Ali, N., and Randhawa, G. (2015). UK Pakistani views on the adverse health risks associated with consanguineous marriages. J. Community Genet. 6, 331-342. doi:10.1007/s12687-015-0214-8.

Akrami, S. M., and Osati, Z. (2007). IS CONSANGUINEOUS MARRIAGE RELIGIOUSLY ENCOURAGED? ISLAMIC AND IRANIAN CONSIDERATIONS. J. Biosoc. Sci. 39, 313-316. doi:10.1017/S0021932006001684.

Al Aqeel, A. I. (2007). Islamic ethical framework for research into and prevention of genetic diseases. Nat. Genet. 39, 1293-1298. doi:10.1038/ng.2007.14.

Al Talabani, J., Shubbar, A. I., and Mustafa, K. E. (1998). Major congenital malformations in United Arab Emirates (UAE): need for genetic counselling. Ann. Hum. Genet. 62, 411-418. doi:10.1046/j.1469-1809.1998.6250411.x.

Alba, R., and Nee, V. (1997). Rethinking Assimilation Theory for a New Era of Immigration. Int. Migr. Rev. 31, 826-874. doi:10.2307/2547416.

Albert, M., Laberge, S., Hodges, B. D., Regehr, G., and Lingard, L. (2008). Biomedical scientists' perception of the social sciences in health research. Soc. Sci. Med. 66, 2520-2531. doi:10.1016/j.socscimed.2008.01.052.

Alexander, J. C. (1994). Modern, Anti, Post, and Neo: How Social Theories Have Tried to Understand the "New World" of "Our Time." Z. Für Soziol. 23, 165-197. doi:10.1515/zfsoz-1994-0301.

Al-Gazali, L., and Hamamy, H. (2014). Consanguinity and dysmorphology in Arabs. Hum. Hered. 77, 93-107. doi:10.1159/000360421. 
Amberger, J. S., Bocchini, C. A., Schiettecatte, F., Scott, A. F., and Hamosh, A. (2015). OMIM.org: Online Mendelian Inheritance in Man (OMIM $\left.{ }^{\circledR}\right)$, an online catalog of human genes and genetic disorders. Nucleic Acids Res. 43, D789-D798. doi:10.1093/nar/gku1205.

Anderson, N. F. (1986). Cousin Marriage in Victorian England. J. Fam. Hist. 11, 285-301. doi:10.1177/036319908601100305.

Anwar, W. A., Khyatti, M., and Hemminki, K. (2014). Consanguinity and genetic diseases in North Africa and immigrants to Europe. Eur. J. Public Health 24, 57-63. doi:10.1093/eurpub/cku104.

Barbouche, M.-R., Galal, N., Ben-Mustapha, I., Jeddane, L., Mellouli, F., Ailal, F., et al. (2011). Primary immunodeficiencies in highly consanguineous North African populations. Ann. N. Y. Acad. Sci. 1238, 42-52. doi:10.1111/j.1749-6632.2011.06260.x.

Barbour, B., and Salameh, P. (2009). CONSANGUINITY IN LEBANON: PREVALENCE, DISTRIBUTION AND DETERMINANTS. J. Biosoc. Sci. 41, 505-517. doi:10.1017/S0021932009003290.

Baykara-Krumme, H. (2016). Consanguineous Marriage in Turkish Families in Turkey and in Western Europe. Int. Migr. Rev. 50, 568-598. doi:10.1111/imre.12176.

Bennett, R. L., Motulsky, A. G., Bittles, A., Hudgins, L., Uhrich, S., Doyle, D. L., et al. (2002). Genetic Counseling and Screening of Consanguineous Couples and Their Offspring: Recommendations of the National Society of Genetic Counselors. J. Genet. Couns. 11, 97-119. doi:10.1023/A:1014593404915.

Berghe, P. L. van den (1983). Human inbreeding avoidance: Culture in nature. Behav. Brain Sci. 6, 91-102. doi:10.1017/S0140525X00014850.

Berra, T. M., Alvarez, G., and Ceballos, F. C. (2010). Was the Darwin/Wedgwood Dynasty Adversely Affected by Consanguinity? BioScience 60, 376-383. doi:10.1525/bio.2010.60.5.7.

Bittles, A. (2001). Consanguinity and its relevance to clinical genetics. Clin. Genet. 60, 89-98. doi:10.1034/j.13990004.2001.600201.x.

Bittles, A. H. (2005). Endogamy, Consanguinity and Community Disease Profiles. Public Health Genomics 8, 17-20. doi:10.1159/000083332.

Bittles, A. H. (2008). A Community Genetics Perspective on Consanguineous Marriage. Public Health Genomics 11, 324-330. doi:10.1159/000133304.

Bittles, A. H. (2011). Time to Get Real: Investigating Potential Beneficial Genetic Aspects of Consanguinity. Public Health Genomics 14, 169-171. doi:10.1159/000321772.

Bittles, A. H. (2013). Consanguineous marriages and congenital anomalies. The Lancet 382, 1316-1317. doi:10.1016/S0140-6736(13)61503-2.

Bittles, A. H., and Black, M. L. (2010). Consanguinity, human evolution, and complex diseases. Proc. Natl. Acad. Sci. 107, 1779-1786. doi:10.1073/pnas.0906079106.

Bittles, A. H., Mason, W. M., Greene, J., and Rao, N. A. (1991). Reproductive behavior and health in consanguineous marriages. Science 252, 789-794.

Bittles, A. H., and Small, N. A. (2016). CONSANGUINITY, GENETICS AND DEFINITIONS OF KINSHIP IN THE UK PAKISTANI POPULATION. J. Biosoc. Sci. 48, 844-854. doi:10.1017/S0021932015000449.

Brubaker, R. (2001). The return of assimilation? Changing perspectives on immigration and its sequels in France, Germany, and the United States. Ethn. Racial Stud. 24, 531-548. doi:10.1080/01419870120049770.

Bubela, T., Li, M. D., Hafez, M., Bieber, M., and Atkins, H. (2012). Is belief larger than fact: expectations, optimism and reality for translational stem cell research. BMC Med. 10, 133. doi:10.1186/1741-7015-10-133.

Chaix, R., Cao, C., and Donnelly, P. (2008). Is Mate Choice in Humans MHC-Dependent? PLOS Genet. 4, e1000184. doi:10.1371/journal.pgen.1000184.

Coornaert, B., Baens, M., Heyninck, K., Bekaert, T., Haegman, M., Staal, J., et al. (2008). T cell antigen receptor stimulation induces MALT1 paracaspase-mediated cleavage of the NF-kappaB inhibitor A20. Nat Immunol 9 , $263-71$.

Darr, A., and Modell, B. (1988). The frequency of consanguineous marriage among British Pakistanis. J. Med. Genet. 25, 186-190. doi:10.1136/jmg.25.3.186.

Darr, A., Small, N., Ahmad, W. I. U., Atkin, K., Corry, P., Benson, J., et al. (2013). Examining the family-centred approach to genetic testing and counselling among UK Pakistanis: a community perspective. J. Community Genet. 4, 49-57. doi:10.1007/s12687-012-0117-x.

Denic, S., Nagelkerke, N., and Agarwal, M. M. (2008). Consanguineous marriages and endemic malaria: can inbreeding increase population fitness? Malar. J. 7, 150. doi:10.1186/1475-2875-7-150.

Denic, S., Nagelkerke, N., and Agarwal, M. M. (2011). On Some Novel Aspects of Consanguineous Marriages. Public Health Genomics 14, 162-168. doi:10.1159/000321771.

Devillé, W., Greacen, T., Bogic, M., Dauvrin, M., Dias, S., Gaddini, A., et al. (2011). Health care for immigrants in Europe: Is there still consensus among country experts about principles of good practice? A Delphi study. BMC Public Health 11, 699. doi:10.1186/1471-2458-11-699. 
Do, Q.-T., Iyer, S., and Joshi, S. (2012). The Economics of Consanguineous Marriages. Rev. Econ. Stat. 95, $904-$ 918. doi:10.1162/REST_a_00279.

Egerbladh, I., and Bittles, A. H. (2011). Socioeconomic, demographic and legal influences on consanguinity and kinship in northern coastal Sweden 1780-1899. J. Biosoc. Sci. 43, 413-435. doi:10.1017/S0021932011000125.

El Mouzan, M. I., Al Salloum, A. A., Al Herbish, A. S., Qurachi, M. M., and Al Omar, A. A. (2008). Consanguinity and major genetic disorders in Saudi children: a community-based cross-sectional study. Ann. Saudi Med. 28, 169-173.

Frets, P. G., Duivenvoorden, H. J., Verhage, F., Niermeijer, M. F., van de Berge, S. M. M., and Galjaard, H. (1990). Factors influencing the reproductive decision after genetic counseling. Am. J. Med. Genet. 35, 496-502. doi:10.1002/ajmg.1320350411.

Fung, W. L. A., Butcher, N. J., Costain, G., Andrade, D. M., Boot, E., Chow, E. W. C., et al. (2015). Practical guidelines for managing adults with 22q11.2 deletion syndrome. Genet. Med. Off. J. Am. Coll. Med. Genet. 17, 599609. doi:10.1038/gim.2014.175.

Gans, H. J. (1997). Toward a Reconciliation of "Assimilation" and "Pluralism": The Interplay of Acculturation and Ethnic Retention. Int. Migr. Rev. 31, 875-892. doi:10.2307/2547417.

Grob, B., Knapp, L. A., Martin, R. D., and Anzenberger, G. (1998). The Major Histocompatibility Complex and Mate Choice: Inbreeding Avoidance and Selection of Good Genes. Exp. Clin. Immunogenet. 15, $119-129$. doi:10.1159/000019063.

Hamamy, H. (2012). Consanguineous marriages. J. Community Genet. 3, 185-192. doi:10.1007/s12687-011-0072-y.

Hamamy, H., Antonarakis, S. E., Cavalli-Sforza, L. L., Temtamy, S., Romeo, G., Kate, L. P. T., et al. (2011). Consanguineous marriages, pearls and perils: Geneva International Consanguinity Workshop Report. Genet. Med. 13, 841-847. doi:10.1097/GIM.0b013e318217477f.

Havlicek, J., and Roberts, S. C. (2009). MHC-correlated mate choice in humans: A review. Psychoneuroendocrinology 34, 497-512. doi:10.1016/j.psyneuen.2008.10.007.

Haynes, R. (2003). From Alchemy to Artificial Intelligence: Stereotypes of the Scientist in Western Literature. Public Underst. Sci. 12, 243-253. doi:10.1177/0963662503123003.

Hoben, A. D., Buunk, A. P., Fincher, C. L., Thornhill, R., and Schaller, M. (2010). On the Adaptive Origins and Maladaptive Consequences of Human Inbreeding: Parasite Prevalence, Immune Functioning, and Consanguineous Marriage. Evol. Psychol. 8, 147470491000800420. doi:10.1177/147470491000800408.

Hotta, A., and Yamanaka, S. (2015). From Genomics to Gene Therapy: Induced Pluripotent Stem Cells Meet Genome Editing. Annu. Rev. Genet. 49, 47-70. doi:10.1146/annurev-genet-112414-054926.

Hunt, P. (2007). Right to the highest attainable standard of health. The Lancet 370, 369-371. doi:10.1016/S01406736(07)61173-8.

Jaber, L., Halpern, G. J., and Shohat, M. (1998). The Impact of Consanguinity Worldwide. Public Health Genomics 1, 12-17. doi:10.1159/000016130.

Jaber, L., Halpern, G. J., and Shohat, T. (2000). Trends in the frequencies of consanguineous marriages in the Israeli Arab community. Clin. Genet. 58, 106-110. doi:10.1034/j.1399-0004.2000.580203.x.

Jaouad, I. C., Elalaoui, S. C., Sbiti, A., Elkerh, F., Belmahi, L., and Sefiani, A. (2009). CONSANGUINEOUS MARRIAGES IN MOROCCO AND THE CONSEQUENCE FOR THE INCIDENCE OF AUTOSOMAL RECESSIVE DISORDERS. J. Biosoc. Sci. 41, 575-581. doi:10.1017/S0021932009003393.

Jones, D. F. (1917). Dominance of Linked Factors as a Means of Accounting for Heterosis. Genetics 2, 466-479.

Joseph, N., Pavan, K. K., Ganapathi, K., Apoorva, P., Sharma, P., and Jhamb, J. A. (2015). Health Awareness and Consequences of Consanguineous Marriages: A Community-Based Study. J. Prim. Care Community Health 6, 121127. doi:10.1177/2150131914557496.

Kagan, J. (2009). The Three Cultures: Natural Sciences, Social Sciences, and the Humanities in the 21st Century. Cambridge University Press.

Kavka, G. S. (1982). The Paradox of Future Individuals. Philos. Public Aff. 11, 93-112.

Kerr, A., and Cunningham-Burley, S. (2000). On Ambivalence and Risk: Reflexive Modernity and the New Human Genetics. Sociology 34, 283-304. doi:10.1177/S0038038500000183.

King, D. S. (1999). Preimplantation genetic diagnosis and the "new" eugenics. J. Med. Ethics 25, $176-182$. doi:10.1136/jme.25.2.176.

Kirby, D. A. (2008). "Hollywood Knowledge: Communication Between Scientific and Entertainment Cultures," in Communicating Science in Social Contexts, eds. D. Cheng, M. Claessens, T. Gascoigne, J. Metcalfe, B. Schiele, and S. Shi (Springer Netherlands), 165-180. doi:10.1007/978-1-4020-8598-7_10.

Koc, I. (2008). PREVALENCE AND SOCIODEMOGRAPHIC CORRELATES OF CONSANGUINEOUS MARRIAGES IN TURKEY.J. Biosoc. Sci. 40, 137-148. doi:10.1017/S002193200700226X.

Kuntz, M. (2012). The postmodern assault on science. EMBO Rep. 13, 885-889. doi:10.1038/embor.2012.130. 
Kuper, A. (2002). Incest, Cousin Marriage, and the Origin of the Human Sciences in Nineteenth-Century England. Past Present, 158-183.

Kymlicka, W. (1995). Multicultural Citizenship: A Liberal Theory of Minority Rights. Clarendon Press.

Levin, B. W., and Browner, C. H. (2005). The social production of health: Critical contributions from evolutionary, biological, and cultural anthropology. Soc. Sci. Med. 61, 745-750. doi:10.1016/j.socscimed.2004.08.048.

Ma, A. (1999). Counselling about genetic disease: an Islamic perspective. East. Mediterr. Health J. Rev. Sante Mediterr. Orient. Al-Majallah Al-Sibhiyab Li-Sharq Al-Mutawassit 5, 1129-1133.

Magnus, P., Berg, K., and Bjerkedal, T. (1985). Association of parental consanguinity with decreased birth weight and increased rate of early death and congenital malformations. Clin. Genet. 28, 335-342. doi:10.1111/j.13990004.1985.tb00407.x.

Marioni, R. E., Davies, G., Hayward, C., Liewald, D., Kerr, S. M., Campbell, A., et al. (2014). Molecular genetic contributions to socioeconomic status and intelligence. Intelligence 44, 26-32. doi:10.1016/j.intell.2014.02.006.

Mc Guire, C., Elton, L., Wieghofer, P., Staal, J., Voet, S., Demeyer, A., et al. (2014). Pharmacological inhibition of MALT1 protease activity protects mice in a mouse model of multiple sclerosis. J. Neuroinflammation 11, 124. doi:10.1186/1742-2094-11-124.

McGuinness, D., McGlynn, L. M., Johnson, P. C., MacIntyre, A., Batty, G. D., Burns, H., et al. (2012). Socioeconomic status is associated with epigenetic differences in the pSoBid cohort. Int. J. Epidemiol. 41, 151-160. doi:10.1093/ije/dyr215.

Meyer, B. F. (2005). Strategies for the prevention of hereditary diseases in a highly consanguineous population. Ann. Hum. Biol. 32, 174-179. doi:10.1080/03014460500075217.

Modell, B., and Darr, A. (2002). Genetic counselling and customary consanguineous marriage. Nat. Rev. Genet. 3, 225-229. doi:10.1038/nrg754.

Morris, Z. S., Wooding, S., and Grant, J. (2011). The answer is 17 years, what is the question: understanding time lags in translational research. J. R. Soc. Med. 104, 510-520. doi:10.1258/jrsm.2011.110180.

Morton, N. E. (1958). Empirical Risks in Consanguineous Marriages: Birth Weight, Gestation Time, and Measurements of Infants. Am. J. Hum. Genet. 10, 344-349.

Panter-Brick, C. (1991). Parental responses to consanguinity and genetic disease in Saudi Arabia. Soc. Sci. Med. 33, 1295-1302. doi:10.1016/0277-9536(91)90078-Q.

Patton, M. A. (2005). Genetic studies in the Amish community. Ann. Hum. Biol. 32, 163-167. doi:10.1080/03014460500075274.

Pillay, N. (2008). Right to health and the Universal Declaration of Human Rights. The Lancet 372, 2005-2006. doi:10.1016/S0140-6736(08)61783-3.

Rao, P. S., Inbaraj, S. G., and Jesudian, G. (1972). Rural-urban differentials in consanguinity. J. Med. Genet. 9, 174 178.

Rao, T. S. S., Asha, M. R., Sambamurthy, K., and Rao, K. S. J. (2009). Consanguinity: Still a challenge. Indian J. Psychiatry 51, 3-5. doi:10.4103/0019-5545.44897.

Raz, A. E. (2003). 'Aysha': Genetics Education and Community Engagement in a Consanguineous ArabBedouin Population in Israel. Heal. Interdiscip. J. Soc. Study Health Illn. Med. 7, 439-461. doi:10.1177/13634593030074004.

Raz, A. E., Atar, M., Rodnay, M., Shoham-Vardi, I., and Carmi, R. (2003). Between Acculturation and Ambivalence: Knowledge of Genetics and Attitudes towards Genetic Testing in a Consanguineous Bedouin Community. Public Health Genomics 6, 88-95. doi:10.1159/000073004.

Reiners, G. (2001). The Post-Migration Survival of Traditional Marriage Patterns: Consanguineous Marriages among Turks and Moroccans in Belgium. J. Comp. Fam. Stud. 32, 21-45.

Restifo, L. L., and Phelan, G. R. (2011). The cultural divide: exploring communication barriers between scientists and clinicians. Dis. Model. Mech. 4, 423-426. doi:10.1242/dmm.008177.

Rezaei, N., Pourpak, Z., Aghamohammadi, A., Farhoudi, A., Movahedi, M., Gharagozlou, M., et al. (2006). Consanguinity in Primary Immunodeficiency Disorders; the Report from Iranian Primary Immunodeficiency Registry. Am.J. Reprod. Immunol. 56, 145-151. doi:10.1111/j.1600-0897.2006.00409.x.

Rich, S. E. (2016). (Mis)Understanding Sufferers with Rare Health Problems. Eur. J. Sociol. Anthropol. 1, 1-7. doi:10.20897/ejsa.201601.

Richards, M. p. m. (1993). The new genetics: some issues for social scientists. Sociol. Health Illn. 15, 567-586. doi:10.1111/j.1467-9566.1993.tb00363.x.

Rozmus, J., McDonald, R., Fung, S.-Y., Del Bel, K. L., Roden, J., Senger, C., et al. (2016). Successful clinical treatment and functional immunological normalization of human MALT1 deficiency following hematopoietic stem cell transplantation. Clin. Immunol. Orlando Fla 168, 1-5. doi:10.1016/j.clim.2016.04.011. 
Rudan, I., Biloglav, Z., Vorko-Jović, A., Kujundžić-Tiljak, M., Stevanović, R., Ropac, D., et al. (2006). Effects of Inbreeding, Endogamy, Genetic Admixture, and Outbreeding on Human Health: A “1001 Dalmatians" Study. Croat. Med. J. 47, 601-610.

Rudan, I., Carothers, A. D., Polasek, O., Hayward, C., Vitart, V., Biloglav, Z., et al. (2008). Quantifying the increase in average human heterozygosity due to urbanisation. Eur. J. Hum. Genet. EJHG 16, $1097-1102$. doi:10.1038/ejhg.2008.48.

Saadat, M., Ansari-Lari, M., and Farhud, D. D. (2004). Short ReportConsanguineous marriage in Iran. Ann. Hum. Biol. 31, 263-269. doi:10.1080/03014460310001652211.

Saleheen, D., Natarajan, P., Armean, I. M., Zhao, W., Rasheed, A., Khetarpal, S. A., et al. (2017). Human knockouts and phenotypic analysis in a cohort with a high rate of consanguinity. Nature 544, $235-239$. doi:10.1038/nature22034.

Schulpen, T. W. J., Wieringen, V., C.m, J., Brummen, V., J, P., Riel, V., et al. (2006). Infant mortality, ethnicity, and genetically determined disorders in The Netherlands. Eur. J. Public Health 16, $290-293$. doi:10.1093/eurpub/cki201.

Shaw, A. (2001). Kinship, Cultural Preference and Immigration: Consanguineous Marriage Among British Pakistanis. J. R. Anthropol. Inst. 7, 315-334. doi:10.1111/1467-9655.00065.

Shaw, A. (2011). Risk and reproductive decisions: British Pakistani couples' responses to genetic counselling. Soc. Sci. Med. 73, 111-120. doi:10.1016/j.socscimed.2011.04.011.

Shaw, A., and Hurst, J. A. (2008). "What is this Genetics, Anyway?” Understandings of Genetics, Illness Causality and Inheritance Among British Pakistani Users of Genetic Services. J. Genet. Couns. $17,373$. doi:10.1007/s10897-008-9156-1.

Sheridan, E., Wright, J., Small, N., Corry, P. C., Oddie, S., Whibley, C., et al. (2013). Risk factors for congenital anomaly in a multiethnic birth cohort: an analysis of the Born in Bradford study. Lancet Lond. Engl. 382, 13501359. doi:10.1016/S0140-6736(13)61132-0.

Shiloh, S., Reznik, H., Bat-Miriam-Katznelson, M., and Goldman, B. (1995). Pre-marital genetic counselling to consanguineous couples: Attitudes, beliefs and decisions among counselled, noncounselled and unrelated couples in Israel. Soc. Sci. Med. 41, 1301-1310. doi:10.1016/0277-9536(94)00433-T.

Small, N., Bittles, A. H., Petherick, E. S., and Wright, J. (2016). ENDOGAMY, CONSANGUINITY AND THE HEALTH IMPLICATIONS OF CHANGING MARITAL CHOICES IN THE UK PAKISTANI COMMUNITY. J. Biosoc. Sci., 1-12. doi:10.1017/S0021932016000419.

Sniekers, S., Stringer, S., Watanabe, K., Jansen, P. R., Coleman, J. R. I., Krapohl, E., et al. (2017). Genome-wide association meta-analysis of 78,308 individuals identifies new loci and genes influencing human intelligence. Nat. Genet. doi:10.1038/ng.3869.

Stoltenberg, C., Magnus, P., Lie, R. T., Daltveit, A. K., and Irgens, L. M. (1997). Birth Defects and Parental Consanguinity in Norway. Am. J. Epidemiol. 145, 439-448. doi:10.1093/oxfordjournals.aje.a009126.

Sulem, P., Helgason, H., Oddson, A., Stefansson, H., Gudjonsson, S. A., Zink, F., et al. (2015). Identification of a large set of rare complete human knockouts. Nat. Genet. 47, 448-452. doi:10.1038/ng.3243.

Sutter, J., and Goux, J.-M. (1964). Decline of consanguineous marriages in France from 1926 to 1958 . Eugen. Q. 11, 127-140. doi:10.1080/19485565.1964.9987584.

Teeuw, M. E., Loukili, G., Bartels, E. A., ten Kate, L. P., Cornel, M. C., and Henneman, L. (2014). Consanguineous marriage and reproductive risk: attitudes and understanding of ethnic groups practising consanguinity in Western society. Eur. J. Hum. Genet. 22, 452-457. doi:10.1038/ejhg.2013.167.

Thelen, T. H. (1983). Minority type human mate preference. Soc. Biol. 30, 162-180. doi:10.1080/19485565.1983.9988531.

Tilley, J. J. (2000). Cultural Relativism. Hum. Rights Q. 22, 501-547. doi:10.1353/hrq.2000.0027.

Tsoi, L. C., Stuart, P. E., Tian, C., Gudjonsson, J. E., Das, S., Zawistowski, M., et al. (2017). Large scale metaanalysis characterizes genetic architecture for common psoriasis associated variants. Nat. Commun. 8, 15382. doi:10.1038/ncomms15382.

Turkheimer, E., Haley, A., Waldron, M., D’Onofrio, B., and Gottesman, I. I. (2003). Socioeconomic Status Modifies Heritability of IQ in Young Children. Psychol. Sci. 14, 623-628. doi:10.1046/j.09567976.2003.psci_1475.x.

Tuvblad, C., Grann, M., and Lichtenstein, P. (2006). Heritability for adolescent antisocial behavior differs with socioeconomic status: gene-environment interaction. J. Child Psychol. Psychiatry 47, 734-743. doi:10.1111/j.14697610.2005.01552.x.

Verma, I. C. (2000). Burden of genetic disorders in india. Indian J. Pediatr. 67, 893-898. doi:10.1007/BF02723953.

Wiles, R., Cott, C., and Gibson, B. E. (2008). Hope, expectations and recovery from illness: a narrative synthesis of qualitative research. J. Adv. Nurs. 64, 564-573. doi:10.1111/j.1365-2648.2008.04815.x. 
Zaidi, A. U., and Shuraydi, M. (2002). Perceptions of Arranged Marriages by Young Pakistani Muslim Women Living in a Western Society. J. Comp. Fam. Stud. 33, 495-514.

Zechenter, E. M. (1997). In the Name of Culture: Cultural Relativism and the Abuse of the Individual. J. Anthropol. Res. 53, 319-347. doi:10.1086/jar.53.3.3630957. 